\title{
Comparison of the frequency of mathematics teachers' use of mathematics textbooks in face-to-face and distance education
}

\author{
Eyüp Sevimli \\ İstanbul Medeniyet University, İstanbul, Turkey, eyup.sevimli@medeniyet.edu.tr \\ Sedef Çelik \\ Artvin Çoruh University, Artvin, Turkey, sedefcelik@artvin.edu.tr \\ Ümit Kul ${ }^{\mathbb{D}}$ \\ Artvin Çoruh University, Artvin, Turkey, umitkul@artvin.edu.tr
}

ABSTRACT Understanding the variables that affect the use of textbooks are important for the development of eligible and preferable resources. In this research, the frequency of textbook usage in face-to-face and distance education was examined according to grade level, professional experience of teachers, and residential area of the schools in which teachers work. The sample of the study consists of 287 middle school mathematics teachers working in different state schools. Data was obtained through an online survey. This study showed that the frequency of textbook usage decreased as the grade level increased, and this decrease occurred both in face-to-face and distance education. However, it has been concluded that the frequency of textbook usage varies in both learning environments according to teaching experience, and that change is statistically significant. In face-to-face classrooms, it was determined that the location of the school was a determining factor in terms of the frequency of textbook usage, whereas, in distance education, the frequency of textbook usage did not statistically significantly differ according to school location. The rest of the findings are discussed in terms of teachers' experiences and attitudes.

Keywords: Distance education, Face-to-face education, Mathematics textbook

\section{Matematik öğretmenlerinin yüz yüze ve uzaktan eğitimde matematik ders kitabı kullanma sıklığının karşılaştırılması}

ÖZ Öğrenme-öğretme sürecinin en önemli materyallerinden biri olan ders kitaplarının kullanımına etki eden değişkenleri anlamak, nitelikli ve tercih edilebilir kaynakların geliştirilebilmesi için önemlidir. $\mathrm{Bu}$ araştırmada, yüz yüze ve uzaktan eğitim sürecindeki ders kitabı kullanım sıklığı, öğretmenlerin mesleki deneyimleri ve görev yaptıkları okulların bulunduğu bölgedeki sosyo-ekonomik düzeylere göre sınanmıştır. Tarama deseni ile yürütülen çalışmanın katılımcılarını 287 ortaokul matematik öğretmeni oluşturmaktadır. Sınıf kademesi, mesleki deneyim ve yerleşim bölgesi dikkate alınarak oluşturulan örneklemden çevrimiçi anket yoluyla toplanan veriler, betimsel ve kestirimsel istatistik teknikleri ile analiz edilmiştir. Çalışma sonuçları, sınıf kademesi arttıkça ders kitabı kullanım oranının azaldığını ve bu azalışın hem yüz yüze hem de uzaktan eğitim sınıflarında gerçekleştiğini göstermiştir. Bununla birlikte, mesleki deneyime göre ders kitabı kullanım sıklığının hem yüz yüze hem de uzaktan öğretim sürecinde değiştiği ve bu değişimin istatistiksel olarak anlamlı olduğu sonucuna ulaşılmıştır. Yüz yüze eğitimde yerleşim bölgesinin ders kitabı kullanım sıklığı açısından belirleyici bir faktör olduğu, uzaktan eğitim sürecinde ise ders kitabı kullanım sıklığının yerleşim bölgesine göre istatistiksel olarak anlamlı bir şekilde farklı olmadığı belirlenmiştir. Diğer bulgular öğretici deneyimi ve tutumları çerçevesinde tartışılmıştır.

Anahtar

Sözcükler: Matematik ders kitabı, Uzaktan eğitim, Yüz yüze eğitim

\footnotetext{
Citation:

Sevimli, E., Çelik, S., \& Kul, Ü. (2022). Comparison of the frequency of mathematics teachers' use of mathematics textbooks in face-to-face and distance education. Turkish Journal of Education, 11(1), 16-35. https://doi.org/10.19128/turje.896355
} 


\section{INTRODUCTION}

Textbooks are supporting elements of educational activities and are prepared based on the national curriculum framework. They have been used by both teachers and students from ancient times to the present day so as to easily access valid and formal information. This allows easy access to the source of scientific knowledge by means of printed or electronic materials (Pepin et al., 2017). Textbooks are the main curriculum resource for active use in classrooms approved by official institutions and developed to provide sanctioned and authorized pedagogical knowledge (Glasnović Gracin \& Jukić Matić, 2016). Even though it is said that textbooks will gradually disappear from the market with the fascinating developments in the digital age, they continue to be included in the education system of most countries in different forms (printed or electronic) (Jhangiani et al., 2018). Even in developing countries that are successful in the international large-scale assessments, it is intended to promote the use of textbooks in teaching in order to improve educational quality and is criticized for not being used adequately (Oates, 2014). In Far East countries such as Singapore, Hong Kong and South Korea, which have always ranked high in these exams, textbooks are seen as an indispensable material of instruction (Fan et al., 2021; Oates, 2014). Textbooks are the most effective resource in favor of mathematics teaching and learning among school subjects (Haggart \& Pepin, 2002; Fan et al., 2013), and they are used by learners in the self-regulation process of knowledge. Teachers utilize mathematics textbooks to comprehend the curriculum goals and to shape their classroom practices at different stages of schooling since they play a major role in providing mathematical knowledge (Fan et al., 2021).

Textbooks play an important role in distance education as well as in face-to-face education, to ensure that the instructors adhere to the outcomes in the curriculum and to regulate the self-learning of the students (Yair, 2014). For an e-learning environment where digital resources can be used more, the role of the textbook may have changed or needs to be reviewed (Lau et al., 2018). With the rapid digitalization, teachers easily have access to a variety of learning resources so as to use in their teaching (Pepin et al., 2013; Siedel \& Stylianides, 2018). Because of the change in the teaching environment, there may be differences in the frequency of use of the textbook and these differences may vary according to the characteristics of the instructors and the students. For instance, in online learning environments which are independent of time and place, the teaching experiences of the instructors or the students' access to different learning resources may affect the frequency of using the textbook. By all means, the purpose of using textbooks is as important as the frequency of use in the teaching-learning process. At the same time, understanding the frequency of use of current textbooks give us an idea about instructors' satisfaction with official teaching content. Particularly, after the Covid-19 crisis, which had a global impact and was described by the World Health Organization as a pandemic (Huang et al., 2020), the shift of learning environments to largely distance or hybrid models have gained more importance, and teachers have begun to perform their teaching activities in distance learning environments (Coman et al., 2020). Despite the rapid growth of using textbooks in online environments, there has been no research concentrating on how often teachers use these mathematics textbooks in distance education when planning a lesson yet. In fact, teachers' views on the way of textbook usage in different learning environments are important as they are a guide for the development of textbooks (Yang \& Sianturi, 2017). In this context, the question that comes to mind is "could textbooks, which are the main source used by teachers to support the realization of the intended curriculum goals in their classroom teaching during face-to-face education (Pepin, 2019), be used in distance education that are transformed compulsorily? Due to the change in learning environments (because of the pandemic), it is important to consider how the instructional contents (e.g. textbooks) are used in different environments either for understanding the current situation or for adapting to the new situation. 


\section{Theoretical Framework}

\section{The role and importance of mathematics textbooks}

Textbooks are didactic tools that transform scientific knowledge into information content to be taught in schools (Davis \& Krajcik, 2005; Remillard, 2005). However, textbooks guide teachers in the process of designing the content of mathematical knowledge, most of which would be taught and learned (Haggarty \& Pepin, 2002; Rezat, 2011; Thomson \& Fleming, 2004). Since textbooks are consistent with the goals of the intended curriculum, provide regular knowledge including pre-designed lectures, activities, tasks, assessments, and practices (Howson, 2013; Stein et al., 2007), and create opportunities for teachers to give their time on students' development rather than developing instructional materials (Thomson \& Fleming, 2004; Valverde et al., 2002). In this way, textbooks which provide compatibility between classes, help to handle a mathematics course at the same level in different cities and schools within the same content and learning-teaching process (Fan et al., 2013; Sevimli \& Kul, 2015). Plianram and Inprasitha (2012) describe textbooks as a popular teaching tool that complements and helps the teaching process in schools. In fact, textbooks are an agent for enlightening what should be instructed (Stein et al., 2007) and is frequently viewed as the potentially enacted curriculum (Valverde et al., 2002). Through the content such as examples, exercises, problems, and tasks in the textbooks, which have a key role in learning mathematics, students may experience problem-solving processes on their own. Among the reasons for failure in mathematics courses are factors such as the complex and incomprehensible expressions in textbooks and the inability to relate the examples to everyday life (Uzunöz et al., 2010). In this context, upon preparing textbooks that contain products with complex and multidimensional properties, care should be taken to choose appropriate content so as to facilitate the understanding of the reader (Erbaş et al., 2012). Textbooks are also compulsory in some other countries and the level of teachers using mathematics textbooks may vary from country to country. In a report, Oates (2014) stated that textbook usage is at 70\% in Singapore, which always ranks high in international assessment exams and is at $95 \%$ in Finland while it is at $10 \%$ in the UK, though it has a high ranking. In a report prepared by Mullis et al. (2020) which compares the success of countries, $4^{\text {th }}$ and $8^{\text {th }}$-grade students who have more educational resources at home such as textbooks, worksheets, and internet resources, etc. are more successful in mathematics courses. According to Thompson et al. (2012), textbooks also directly affect the professional development of teachers because they determine the contents that teachers will teach, offer teaching strategies which are appropriate to the student level, and allow students to consolidate what they have learned after the course. In the light of this approach, textbooks are of great importance in the development of the student and in supporting the teacher.

Educational studies on textbooks have gained more importance in recent years and attracted more attention from researchers in the aspects of mathematics education (Fan et al., 2013; Howson, 2013; Pepin et al., 2017; Remillard, 2005). In fact, special issues (e.g., ZDM-2013, 2018) were prepared in journals about mathematics textbooks, and conferences (ICMT-1,2,3) were organized. Fan et al. (2013) in their meta-analysis-based study on the role of textbooks in learning and teaching noted that teachers' use of mathematics textbooks are given less attention in educational research. Similarly, Gökçek and Çelik (2020) examined a total of 114 studies published between the years 2005 and 2019 in their metasynthesis study regarding mathematics textbooks in Turkey. According to the results of this review, there were fewer studies that analyzed the mathematics textbooks $(59 \%)$ rather than the studies that received an opinion from teachers on the use of mathematics textbooks (41\%). Although the features and role of the textbooks in mathematics education have been examined a lot, little is known about how often Turkish teachers use them in both face-to-face and distance education. In fact, Margolinas (2013) explicitly articulated that most teachers use printed textbooks and digital curriculum resources as the main sources in their teaching activities. Therefore, teachers' views on the way of textbook usage in various learning environments are important as they are a guide for the development of textbooks (Yang \& Sianturi, 2017). Due to reasons such as compatibility with the curriculum, however, the multiplicity of teaching materials, and the potential impact of textbook usage on students' learning opportunities (Robitaille \& Travers, 1992), research has to be conducted with teachers about the use of textbooks in teaching. For example, Pepin and Haggarty (2001), criticized research based on the study of textbooks 
only in terms of the text since they are out of context and stated that the findings obtained from these studies would be insufficient to provide information about how teachers use textbooks. In another study, Haggarty and Pepin (2002) pointed out the mediating role of textbooks between teacher and classroom teaching and stated that this kind of role was affected by the cultural structure and school environment of the country. They also mostly use questions similar to the central exam questions that are found in the textbook. Samat and Rosli (2020) found that even though teachers' perceptions of the content and formal characteristics of the textbook were at a high level, their perceptions of the level of textbook usage as well as the nature of exercises and evaluations were at a moderate level. With the development and increased availability of course materials, they offer new teaching and learning opportunities for both teachers and students (Fan, 2013). In addition, printed or electronic textbooks have become more important in terms of their instructional aspects in cases where face-to-face classes cannot take place for some reasons (for example, during the days of the Covid-19 pandemic) and periods when self-study at home is preferred. Understanding the variables that affect the use of textbooks are important for the development of eligible and preferable resources for teachers in the Turkish context.

\section{Digitalization in education and use of mathematics textbooks in Turkish educational context}

Today, learning environments have been shifted to largely distance or hybrid models have gained more importance and teachers have begun to perform teaching activities in distance learning environments (Stephenson, 2018). Similarly, increasing the presence of digital resources and the use of electronic textbooks for mathematics education led to radical changes in education, such as the adoption of user and designer roles by teachers (Pepin et al., 2017). In line with the demands of the new generation (zgeneration) growing up with educational environments and electronic contents enriched with multidimensional and interactive media sources; the need for digital resources in virtual environments has increased even more (Siedel \& Stylianides, 2018). In particular, the widespread use of mobile devices by students also requires that printed books in educational environments be transferred to digital media. By means of the hardware and software technologies they use, electronic books provide a participatory environment as well as presenting rich contents to the learner. Because of this, teachers must have digital pedagogical qualifications. The use of digital textbooks also enables the use of innovative learning and teaching approaches. Beyond having much more flexibility and accessibility than printed textbooks, digital-electronic textbooks help individual learning with the ability to easily integrate various support materials, rather than being visually prominent with their multimedia features (Robinson \& Stubberud, 2012). The fact that students feel more comfortable without a teacher's guide plays an important role in preferring the electronic book (Jou et al., 2016). Activities that can be adapted to the level of students can be applied, by considering individual differences, and various feedbacks can be provided (Siedel \& Stylianides, 2018). For this reason, electronic textbooks are now reflected by the teacher on a $\mathrm{CD}$ or on a website during the lesson; animations, videos and exercises are complemented by different software and digital materials such as providing feedback to students (Gueudet et al., 2013). The studies conducted in the process of distance education have also shown that the use of interactive teaching materials increase students' academic achievement (Yaşlica, 2020). The digital resources help students learn by considering their individual differences, as well as the ease of online access (Gueudet et al., 2013; Robinson \& Stubberud, 2012). Furthermore, with the increasing availability of online curriculum resources, teachers have opportunities to make their decisions concerning the course material selections on the basis of the relationship between material, subject, and student characteristics (Siedel \& Stylianides, 2018). Just as the content preferred by educators may change with the integration of technology into the teaching environment, the transition from face-to-face to distance education might affect instructors' textbook usage and their content preferences.

In mathematics education literature, there are many studies on the levels of the use of the textbook in face-to-face classes and on the characteristics of a preferable mathematics textbook. As yet, there is very little known about mathematics teachers' textbook usage in distance education. In this context, Pepin et al. (2013) draw attention to the use of electronic textbooks in mathematics teaching with the development of technology and state that such books will traditionally change the teacher-textbook, student-textbook, and teacher-student interaction. Researchers note that owing to the spread of 
electronic and interactive textbooks, the ways in which these books are used should be more investigated. Discussing the role of textbook learning resources in e-learning environments through Bloom's taxonomy, Lau et al. (2018) found that most of the textbooks investigated lack the sophistication and complexity to support high-order learning that involves collaboration among learners and facilitators on e-learning platforms. In this current study, since the change in the frequency of Turkish mathematics teachers' textbook use with the transition to distance education is evaluated, this would provide useful information about the place and role of textbooks in the Turkish education system. The Turkish Ministry of Education (MoNE) plays an important role in decision-making in all fields regarding education. The school curriculum is prepared by government institutions. In parallel with the newly developed curriculum, school mathematics textbooks were renewed and revised. Thus, the quality, content, design, and other aspects of textbooks are evaluated and checked by an official commission appointed by MoNE including experts and teachers. Therefore, two types of governmentauthorized textbooks (state and private) are available to all students who spend considerable time using mathematics textbooks at class or at home to do the assigned homework. These books were accepted as textbooks for five-year duration from the year of publication by the decision of the Board of Education. These books which are recommended for use in many Turkish state schools, also available for all students, educators, and parents and are listed on the MONE official website (Kul et al., 2018).

There is an enormous investment by MoNE in the evaluation and distribution of free textbooks resources to all state schools. Textbooks are compulsory at all levels of schooling for many years and teachers are required to follow these textbooks in classrooms since the centralized nature of the Turkish educational system is based on a curriculum. Thus, Turkish teachers actively use textbooks in their daily teaching practices and can often benefit from this curriculum resource to use them in their classrooms (Iş1k, 2008; Korkmaz et al., 2020; Özmantar et al., 2017; Uğurel et al., 2010; Ulusoy \& Incikabi, 2020). Textbooks are designed in coordination with the curriculum, and the weekly distribution of subjects is predetermined. Despite the special supporting materials for teachers and students for the mathematics course in primary and secondary education, the main material followed in the course is common (Altun et al., 2004; Iş1k, 2008). There are some studies in the literature, which evaluated the views of teachers according to various variables such as textbook usage, grade level, professional experience, and the residential area of the school. For instance, Bulut and Tertemiz (2013) in their study found that the use of mathematics textbooks do not significantly differ according to the grade level taught by teachers, but significantly differ according to the experience of teachers in their profession and the socio-economic level of the schools in which teachers work. Tutak and Güder (2012 examined the $5^{\text {th }}$-grade teachers' views about the mathematics textbook according to their professional experience and educational status and found no significant differences between these variables. Özgeldi (2012) found that teachers rarely use the textbook for problems and examples while using the textbook frequently in the preparation process and during the course. Teachers, in particular, benefit from the textbook to relate the subject to daily life, to establish connections with other courses, and to follow the order of the subject.

The studies that investigated why the textbook is not used effectively in Turkey have considered different points. In studies that received views from teachers as to the use of mathematics textbooks, subjects such as the formal and visual features of the textbooks, the effect of central exams, the teaching methods and techniques adopted in content presentation, the number and quality of evaluating questions and activities were emphasized (Korkmaz et al., 2020; Özmantar et al., 2017; Ulusoy \& İncikab1, 2020). For instance, Korkmaz et al. (2020) found that the vast majority of teachers believe that textbooks are not suitable for central exams. Some of them have the opinion that the existing textbooks can be improved by revising some of their features. It has also been found that while the vast majority of teachers do not prefer to actively use textbooks in their classes, textbooks are used often for the purpose of homework assignments (ibid). When teachers think that the textbooks are insufficient, they may direct students to additional resources. Similarly, Özmantar et al. (2017) found that the compulsory textbooks used by teachers who were included in their study did not meet their expectations in terms of questions, lectures, and suitability for student characteristics. All these findings reveal that it is important to investigate the issues affecting teachers' use of the textbook in order to benefit from the textbook more effectively in the classroom. 


\section{The Purpose of the Research}

In the limited number of studies in the related literature, teachers' preferences on textbook usage in faceto-face classes have been discussed in terms of demographic variables. However, no comprehensive study was found which comparatively questioned the frequency of the textbook usage of teachers in face-to-face and distance instruction. Along with the development of technology, other changes in social life and health conditions affecting the educational process pave the way for differences in learning methods and habits. Understanding which variables can affect the frequency of textbook usage in different learning environments and educational approaches will contribute to the effective use of textbooks in the learning-teaching process. Especially in distance education following the pandemic, teachers' thoughts about the necessary qualities and characteristics of mathematics textbooks become important. Therefore, the aim of this study is to compare the frequency of textbook usage of middle school mathematics teachers in face-to-face and distance education in terms of grade level, professional experience, and school location. In accordance with this purpose, answers to the following questions have been sought in face-to-face and distance education:

(1) How does the frequency of the use of middle school mathematics textbooks vary depending on the type of learning environment (face-to-face or distance)?

(2) How does the frequency of mathematics textbooks usage vary in face-to-face and distance education according to grade level?

(3) Is there a significant difference between the frequency of middle school mathematics textbooks usage and the teaching experiences of mathematics teachers? How does the frequency of mathematics textbooks usage vary according to professional experience?

(4) Is there a significant difference between the frequency of middle school mathematics textbooks usage and the socio-economic levels of the schools where the teachers work? How does the frequency of mathematics textbooks vary according to the residential area of the schools?

\section{METHOD}

\section{Research Design and Sampling}

In order to use a data collection and analysis method suitable for the research questions within the scope of the research, a design that is capable of testing the possible relationships between the current situation and incidents over large samples is required. The research, which evaluated the rates of middle school mathematics teachers' usage of existing mathematics textbooks in terms of some variables, was conducted using a survey method. The survey is a research design that is frequently used to define the views and behaviors of a group of participants in the face of an incident or phenomenon, that can also employ different research strategies (qualitative, quantitative, or mixed) through questionnaires, and that has a broad representation and generalization capacity (Check \& Schutt, 2012).

Table 1.

Distribution of Participants According to Teaching Experience

\begin{tabular}{llcc}
\hline Years of experience & Experience group & Frequency & Percent \\
\hline 5 years and less & Less experienced & 87 & $\% 30$ \\
6 to 15 years & Experienced & 132 & $\% 46$ \\
16 years and over & Very experienced & 68 & $\% 24$ \\
\hline
\end{tabular}

Online forms have been used to broadly define middle school mathematics teachers' views on textbook usage in face-to-face and distance education. In this context, 287 mathematics teachers who can be 
reached by e-survey and voluntarily participated in the research constitute the sample of the research. While creating the professional experience groups, the classifications in the TIMMS 2015 national mathematics, as well as science preliminary report and the distribution frequencies of the participants, were considered, and thus a classification of three groups was made as 5 years and less, 6 to 15 years and 16 years and more, in a way to ensure a normal distribution. These groups were named to be less experienced, experienced, and very experienced, respectively, and thus attention was paid to reflect the content with descriptive terminology in terms of the reader. The distribution of participants in professional experience groups is available in Table 1. According to this, 87 (30\%) of the 287 math teachers in the study sample were in the less experienced group, $132(46 \%)$ were in the experienced group, and $68(24 \%)$ were in the very experienced group. As the middle school math teachers in the sample worked in different residential areas of different provinces (14 provinces), the frequency of use of textbooks was also tested within the framework of this feature. Of the 287 middle school mathematics teachers participating in the study, 73 (25\%) work in rural (residential) areas such as villages or towns, and $214(75 \%)$ work in urban areas such as the provincial or district centers. In this sense, it was found that two-thirds of the sample worked in schools in the city center.

Research data was collected through the mathematics textbook evaluation (MTE) form, developed to determine the frequency of mathematics textbook usage by middle school mathematics teachers and available in both face-to-face and distance education. Mathematics textbook evaluation form was prepared within the framework of field observations of students enrolled in the Mathematics Textbook Evaluation course in elementary school mathematics education undergraduate programs and by means of research data in the literature and two experts' opinions. Textbook evaluation forms were examined and benefited from the literature In the relevant literature, it is stated that the years of experience of teachers and the residential areas they serve may affect their attitudes and use of materials in classroom teaching practice (Çetin et al., 2019). From this point of view, in the demographic variables section of the mathematics textbook evaluation form, the sample was expected to indicate their professional experience, the provinces in which they serve, their residential areas, and in which grade level they have taught for the last two years.

Table 2.

An Example from the MTE Form

Indicate your percentage of using the mathematics textbooks while preparing your lecture notes according to the grade level.

\begin{tabular}{llllll}
\hline Grade & Environment & Rarely & Sometimes & Often & Usually \\
$5^{\text {th }}$-grade & Face-to-face & ( ) $0-25 \%$ & ( ) $26-50 \%$ & ( ) $51-75 \%$ & ( ) $76-100 \%$ \\
& Distance & ( ) $0-25 \%$ & ( ) $26-50 \%$ & ( ) $51-75 \%$ & ( ) $76-100 \%$ \\
$6^{\text {th }}$-grade & Face-to-face & ( ) $0-25 \%$ & ( ) $26-50 \%$ & ( ) $51-75 \%$ & ( ) $76-100 \%$ \\
& Distance & ( ) $0-25 \%$ & ( ) $26-50 \%$ & ( ) $51-75 \%$ & ( ) $76-100 \%$ \\
$7^{\text {th }}$-grade & Face-to-face & ( ) $0-25 \%$ & ( ) $26-50 \%$ & ( ) $51-75 \%$ & ( ) $76-100 \%$ \\
& Distance & ( ) $0-25 \%$ & ( ) $26-50 \%$ & ( ) $51-75 \%$ & ( ) $76-100 \%$ \\
$8^{\text {th }}$-grade & Face-to-face & ( ) $0-25 \%$ & ( ) $26-50 \%$ & ( ) $51-75 \%$ & ( ) $76-100 \%$ \\
& Distance & ( ) $0-25 \%$ & ( ) $26-50 \%$ & ( ) $51-75 \%$ & ( ) $76-100 \%$ \\
\hline
\end{tabular}

The MTE form was applied after it was reviewed by experts and mathematics teachers. In the previous form, the teachers were asked to determine the frequency of using the textbook themselves, but some teachers used descriptions instead of numbers. For this reason, the items which are included the frequency of using textbooks were revised in both numbers and descriptions in the final form. Moreover, in order to make the use of the textbook in classroom practice more understandable, the term lecture notes preparation process is included in the items. One of these items is shared in Table 2, and the other items are enriched with information on the demographic variables (professional experience, school location etc.) of the participants. The most important finding to be reached in the form is to determine the rates of textbook usage by teachers within the framework of different grade levels $\left(5^{\text {th }}, 6^{\text {th }}, 7^{\text {th }}\right.$ and $8^{\text {th }}$ grades) in middle school mathematics curricula. To make a comprehensive analysis of the textbooks at each grade level, the frequency of use of mathematics textbooks in different learning areas (numbers and operations, algebra, geometry and measurement, data processing, and probability) were also 
considered. A four-category classification was made so that teachers could give objective evaluations and realistic rates, and verbal and numerical coding was performed for each category. In this sense, the use of the textbook in classroom practice is coded as "Rarely" if it is $25 \%$ and below. It is coded as "Sometimes" if it is between $26 \%-50 \%$. It is "Often" if it is $51 \%-75 \%$. If it is over $76 \%$, it is "Usually".

The draft form was the first subject to expert opinion (two experts with a doctor's degree in mathematics education), and then a pilot study was conducted with 27 participants outside the sample. After the expert opinion, it was deemed appropriate to include the percentage and descriptive codes in the mathematics textbook evaluation form together, and after the pilot study, it was decided to apply the form separately applied for each grade level (to increase the rate of return to the questionnaire and prevent similar answers). In order to confirm the data on the frequency of use of the textbook, two different techniques are employed. First, in order to ensure internal confirmation, questions about the frequency of book use were detailed according to grade level and type of learning area, and overall scoring coding was performed by considering the total scores obtained in this way. In addition, since part of the sample is the mentor teachers of courses conducted within the framework of school experience, the observation notes of the pre-service teachers who observed this sample were used within the scope of the "school experience" course. The results obtained by a group of observers who observed six teachers in both face-to-face and distance learning showed that the frequency of the textbook usage as indicated by the sample and the frequency of the use reported by external observers were consistent at a high level (between $76 \%$ and $87 \%$ ). The MTE form, used to determine the sample's opinions on textbook usage in face-to-face and distance learning, was applied through online survey applications and at different times for each teaching environment. Forms that determine the teachers' opinions of the mathematics textbook in a distance/face-to-face environment have been systematically tried to be delivered to the participants. Thus, the research was carried out in a wide scope, by taking the opinion of mathematics teachers in every region of Turkey.

\section{Analysis of the Data}

Research data have been analyzed by descriptive and predictive statistical techniques. First, the coded data of each teacher in the sample, according to the frequency (percentage) of the textbook usage, was evaluated as a percentage. In the process of coding data and statistical evaluation of codes, two academicians who are experts in the field of mathematics education took part. In this sense, the frequency of the textbook usage in different learning environments and the frequency of the use of textbooks according to the grade level are presented as a percentage. In the process of predictive statistics, the relationship between the levels of frequency of the use of mathematics textbooks and categorical variables such as professional experience and residential area was analyzed using Chi-square tests. It was examined whether there was a significant difference between the distribution of the frequency levels of textbook usage and the distribution of demographic variables. Descriptive statistics have also been used to determine how the frequency of the use of mathematics textbooks varies according to demographic variables in order to support the findings of predictive statistics. In this way, it is possible to describe and explain the results of quantitative statistics and to interpret in detail which variable direction the statistically significant difference is in.

\section{Ethical Procedures}

Ethical principles and rules were followed during the planning of the research, data collection, analysis, and reporting. This research was found ethically appropriate with the decision numbered E-18457941050.01.04-2350 at the meeting held by Artvin Çoruh University Ethics Commission on 27 January 2021. 


\section{FINDINGS}

When the total rate of the use of the mathematics textbook in mathematics teaching was examined, it was found that the frequency of the use of the textbook decreased with the shift from face-to-face classes to distance education. It was observed that the difference in the categories of "Rarely (0-25\%)" and "Often (51-75\%)" was more prominent than in other categories when the ratios of the use of mathematics textbooks in different learning environments were examined categorically. In this sense, in the category of "Rarely", where participants who referred to the textbook less in the math teaching process, $24 \%$ of participants were found in face-to-face classes, while the rate of the participants in the distance education in the same category was $41 \%$.

\section{Figure 1.}

Percent of the Textbook Usage in Face-to-Face and Distance Education

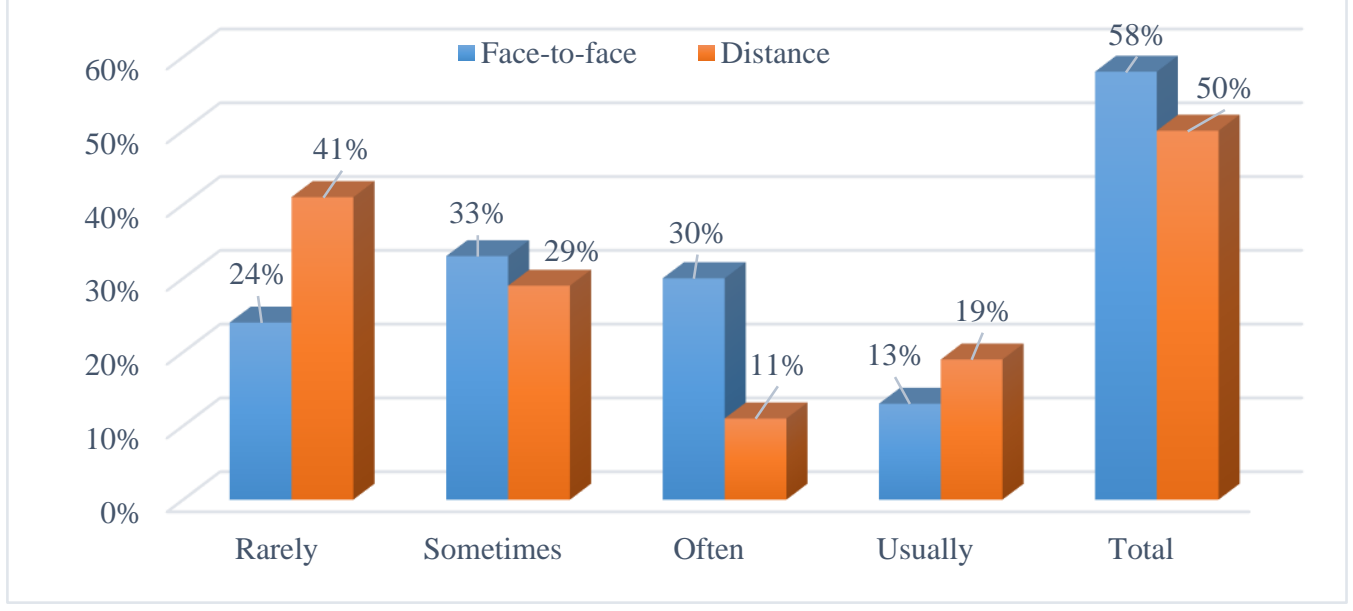

While the category in which participants who constructs more than half of the course content by referring to the textbook source is "Often", the participants in this category are more likely to be in face-to-face classes (30\%) than in distance education (11\%). A close look at the findings in Figure 1 shows that as the frequency of the use of the textbook increases, participants in the relevant category decrease in the distance classroom. The only category left out of this trend was the "Usually (76-100\%)" category. There are more participants in distance education (compared to face-to-face education) in the "Usually" category, which is composed of participants who give place to the textbook very often in mathematics classrooms. Overall findings of the textbook indicate that different demographic variables in the choice of instructional content may also affect the process. In this study, examinations were carried out in terms of grade level, professional experience, and residential area of schools. Findings on the frequency of the use of the textbook in face-to-face and distance education are presented in Figure 1 through the specified categories.

\section{Results about the Frequency of the Textbook Usage According to Grade Level}

Another demographic (categorical) variable considered in this research is the grade level. By crosscomparing data on the grade level and the frequency of textbook usage, participants' preferences on the content in different teaching environments were evaluated. In the study of the results offered in Figure 2 , the grade level at which the rate of textbook usage is highest in both face-to-face classes and distance education process is 5 while the lowest level of the grade is 8 . On the other hand, it is clear that the frequency of textbook usage decreases as the grade level increases in both face-to-face classes and distance education. The grade level where textbook usage begins to decline significantly in both teaching environments has been identified as the $7^{\text {th }}$ Grade. However, Figure 2 indicates that the rate of textbook usage in face-to-face classes for all grade levels is higher than in distance education. 
Figure 2.

Percentage of Textbook Usage in Face-to-Face and Distance Instructions According to Grade Level

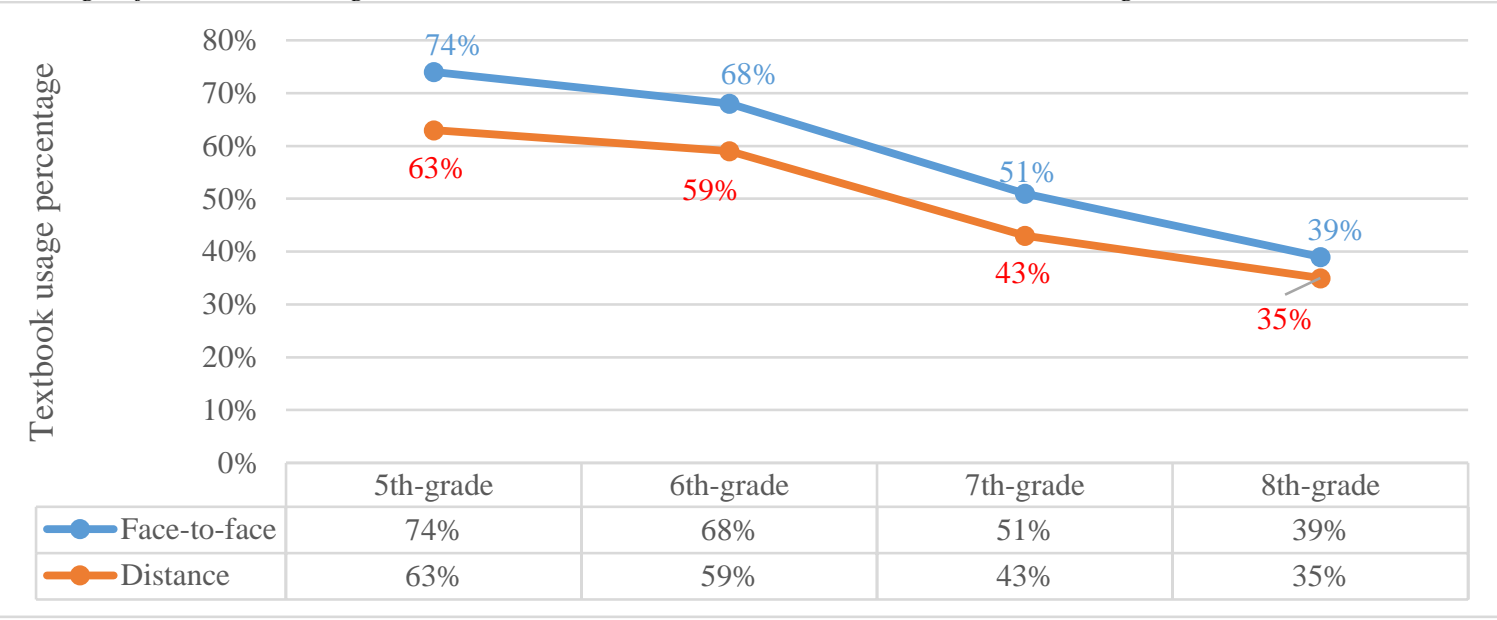

\section{Results about the Frequency of Textbook Usage According to Professional Experience}

In the face-to-face and distance education process, it was observed that the frequency of the textbook usage of mathematics teachers changed to the classroom environment. In this context, Chi-Square analyses were performed by separately examining the frequency of textbook usage in both face-to-face and distance instruction as well as the experiences of mathematics teachers.

Table 3.

Chi-Square Analysis of Frequency of Mathematics Textbook Usage According to Experience Variable

\begin{tabular}{|c|c|c|c|c|c|c|c|}
\hline \multirow{2}{*}{$\begin{array}{c}\text { Learning } \\
\text { Environment }\end{array}$} & \multirow{2}{*}{$\begin{array}{l}\text { Usage } \\
\text { frequency }\end{array}$} & \multicolumn{3}{|c|}{ Professional Experience } & \multirow[b]{2}{*}{ Total } & \multirow[b]{2}{*}{$\mathrm{X}^{2}$} & \multirow[b]{2}{*}{$\mathrm{P}$} \\
\hline & & $\begin{array}{c}\text { Less } \\
\text { experienced }\end{array}$ & Experienced & $\begin{array}{c}\text { Very } \\
\text { experienced }\end{array}$ & & & \\
\hline \multirow{5}{*}{ Face-to-face } & Rarely & 15 & 14 & 40 & 69 & \multirow{5}{*}{42.94} & \multirow{5}{*}{0.001} \\
\hline & Sometimes & 15 & 46 & 36 & 98 & & \\
\hline & Often & 31 & 40 & 12 & 83 & & \\
\hline & Usually & 15 & 14 & 9 & 38 & & \\
\hline & Total & 76 & 113 & 97 & 286 & & \\
\hline \multirow{5}{*}{ Distance } & Rarely & 29 & 61 & 24 & 114 & \multirow{5}{*}{29.03} & \multirow{5}{*}{0.001} \\
\hline & Sometimes & 33 & 31 & 17 & 81 & & \\
\hline & Often & 9 & 7 & 22 & 38 & & \\
\hline & Usually & 16 & 22 & 15 & 296 & & \\
\hline & Total & 87 & 121 & 78 & 286 & & \\
\hline
\end{tabular}

The results of The Chi-Square analysis are available in Table 3, respectively. According to the table, in a face-to-face classroom environment, it was determined that the frequency of use of textbooks differed significantly according to the experiences of mathematics teachers $\left(p<0.05 ; X^{2}=42.94\right)$. In virtual classrooms, it was determined that the frequency of use of textbooks differed significantly according to the experiences of mathematics teachers $\left(\mathrm{p}<0.05 ; \mathrm{X}^{2}=23.036\right)$. Therefore, it can be stated that the 
frequency of the mathematics textbooks usage in both teaching environments differs according to the teachers' teaching experience. On the other hand, the rates of textbook usage in different teaching environments were examined according to the professional experience of the participatory teachers. It was observed that the frequency of textbook usage of participants in the less experienced group decreased with the shift from face-to-face to distance education. More than $30 \%$ of participants with five years or less of professional experience were evaluated in the face-to-face education process and less than $20 \%$ were evaluated in the categories of "Often" and "Usually" the distance learning process. This finding shows that participants in the less experienced group received more than half of the instructional content they offered in face-to-face classes from the textbook and reveals that textbook usage in distance education decreased significantly. It was also determined that participants in the "experienced" group with 6 to 15 years of professional experience benefited more from textbook content in face-to-face education compared to distance education, similar to the less experienced group. The most obvious change in the experienced group was observed in the categories "Rarely" and "often". It was found that with the change in the teaching environment, participants who used the textbook more rarely increased in the experienced group, while the number of those who used it significantly decreased. The findings, reflecting the use of textbooks in face-to-face and distance education according to teaching experience, are offered in Figure 3.

Figure 3.

Percentage of the Textbook Usage in Face-to-Face and Distance Education According to the Teaching Experience

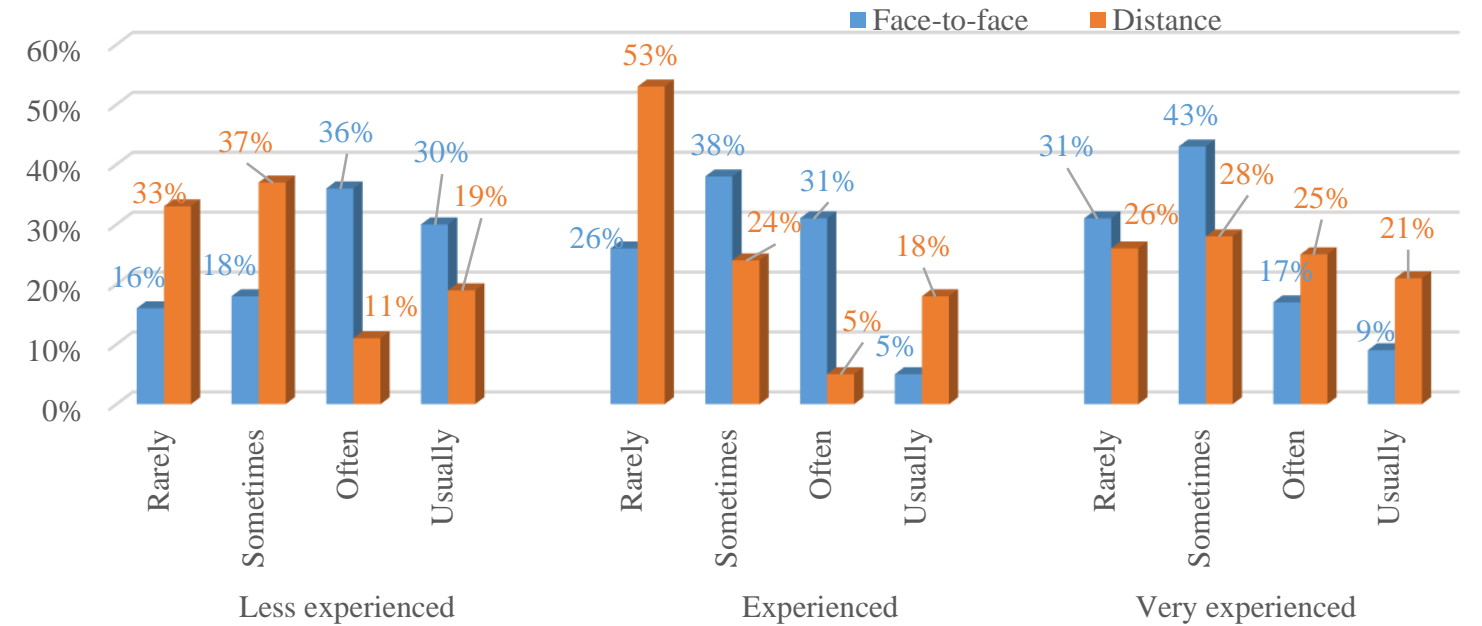

With the shift from face-to-face to distance education, the ratio of the textbook usage of participants in the "very experienced" group, who had more than 15 years of professional experience has increased. About three-quarters of the participants in the highly experienced group use textbooks in face-to-face classes "Rarely" or "Sometimes", while nearly half of the participants in this group were found to use textbooks "Often" and "Usually" in distance education classes. In other words, the shift to distance education increased the tendency of participants in the very experienced group to use textbooks. Compared to the tendency of participants, grouped according to professional experience, to use textbooks, it can be said that participants in the very experienced group, unlike participants in the less experienced and experienced group, used textbooks in distance education compared to face-to-face classes.

When cross-comparison results are made in terms of learning environments, these findings can be obtained; i) The group that uses the textbook the most in face-to-face classes is the least experienced, while the group that uses the textbook the least is the most experienced, ii) The group that uses the textbook the most in the distance learning process is the most experienced, while the group that uses the textbook the least is the experienced group. It was wondered whether the places where teachers work as well as their professional experiences affect their textbook preferences and the relevant findings were shared under the next heading. 


\section{Results on the Frequency of the Textbook Usage According to School Location}

The frequency of the textbook usage in face-to-face and distance instructions as well as the residential areas of mathematics teachers were examined separately. The results reflecting the result of The ChiSquare analysis are available in Table 4, respectively. According to the table, in face-to-face classes, it was found that frequency of use of textbooks differed significantly according to the residential area $\left(\mathrm{p}<0.05 ; \mathrm{X}^{2}=7.968\right)$. Unlike the face-to-face classes, there was no significant difference in the distance education process according to the type of residential area $\left(p>0.05 ; X^{2}=10.753\right)$.

Table 4.

Chi-Square Analysis of Mathematics Textbook Usage According to School Location

\begin{tabular}{|c|c|c|c|c|c|c|}
\hline \multirow[t]{2}{*}{ Learning Environment } & \multirow[t]{2}{*}{ Usage frequency } & \multicolumn{2}{|c|}{ Residential area } & \multirow{2}{*}{ Total } & \multirow{2}{*}{$\mathrm{X}^{2}$} & \multirow{2}{*}{$\mathrm{p}$} \\
\hline & & Urban & Rural & & & \\
\hline \multirow{5}{*}{ Face-to-face } & Rarely & 46 & 23 & 69 & \multirow{5}{*}{7.968} & \multirow{5}{*}{0.04} \\
\hline & Sometimes & 66 & 30 & 96 & & \\
\hline & Often & 70 & 13 & 83 & & \\
\hline & Usually & 29 & 8 & 38 & & \\
\hline & Total & 211 & 75 & 286 & & \\
\hline \multirow{5}{*}{ Distance } & Rarely & 82 & 32 & 114 & \multirow{5}{*}{10.753} & \multirow{5}{*}{0.13} \\
\hline & Sometimes & 53 & 28 & 81 & & \\
\hline & Often & 35 & 3 & 38 & & \\
\hline & Usually & 34 & 1 & 53 & & \\
\hline & Total & 204 & 82 & 286 & & \\
\hline
\end{tabular}

On the other hand, as a part of the research, the frequency of textbook usage was evaluated by considering the residential area of schools where the participants worked. In this sense, the findings on the frequency of the textbook usage of participants working in rural and urban areas were shared in Figure 4.

Figure 4.

Percentage of the Textbook Usage of Participants Working in Rural and Urban Areas

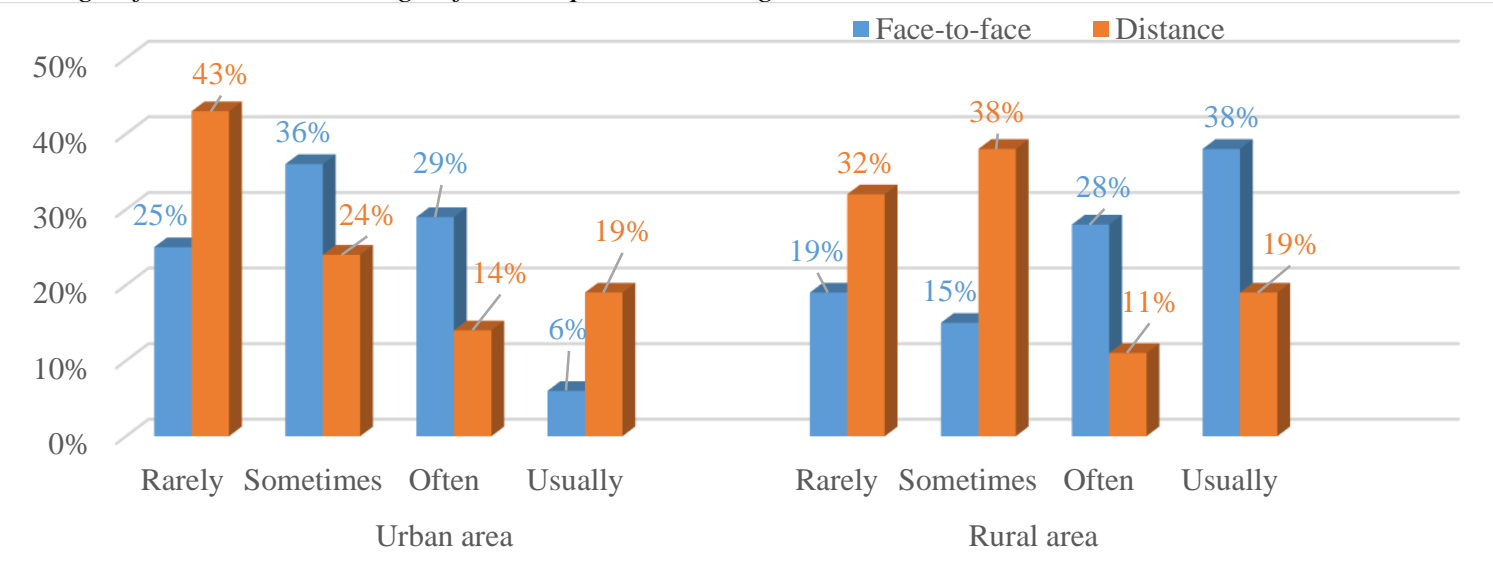


Upon examining the frequency of the use of mathematics textbooks by participants in urban schools, it was found that in face-to-face classes, more teachers were in "Sometimes" and "Often" categories, while in distance education, they were under the categories of "Rarely" and "Sometimes". It was found that the participants working in urban residential areas use the textbook more often in face-to-face classes compared to the distance learning process. Participants in rural residential areas were more likely to be in "often" and "usually" categories in face-to-face classes, while they were more often in the categories of "Rarely" and "Sometimes" in distance education. This finding reveals that in rural areas, participants' textbook usage decreased with the shift from face-to-face to distance education. Upon examining "how textbook usage differs according to the change in the teaching environment" by considering the residential area, it can be said that the frequency of the textbook usage decreases in both urban and rural areas with the shift from face-to-face classes to distance education, but the rate of decline in rural areas is more prominent.

\section{DISCUSSION}

In this study, which examined the effect of the changing classroom environment with the shift from face-to-face education to distance education on the frequency of the textbook usage of mathematics teachers, the frequency of the textbook usage was analyzed in terms of some variables. The present study draws attention to the finding that the rate of textbook usage is further reduced in distance education where technology is used effectively. The low use of mathematics textbooks in distance education classes can be explained by the lack of digital resources in distance education. Digital resources that could not be used flexibly in online classes in a synchronized (student-teacher coordination) way may be less preferred in the distance education process by participants. Işık (2013) also stated the reasons limiting the use of digital resources in a study as the lack of the sufficient number of e-books in different subjects, the need for auxiliary equipment in reading e-books, the inadequacy of individuals in using technological tools and software, etc. In this context, it can be concluded that if the mathematics textbooks to be used in distance education are interactive, the instructors may prefer these resources more. The fact that participants demand more interactive digital content in the distance education process may also mean that they do not find traditional textbooks useful enough. The easy access of different digital platforms or web resources in distance education courses on internet-based video conferencing programs may have reduced the frequency of textbook usage. According to Matzavela and Alepis (2021), intelligent tutoring systems and social networks have had rapid growth in online courses, especially in the COVID-19 era. As a matter of fact, during the Covid -19 pandemic periods, the use of interactive digital resources has become more widespread. In this respect, more social and interactive resources are likely to be preferred by instructors in distance education.

The present study also showed that the rate of teachers' use of math textbooks varies according to the grade level. In $5^{\text {th }}$ grade, in both face-to-face classes and distance education, it was determined that the rate of the use of mathematics textbooks was higher than in other grades. In addition, this study showed that as grade level increased, the rate of textbook usage decreased regardless of the teaching environment. Despite the change in the learning environment, the finding that teachers' textbook usage tendencies show similarity according to grade levels should be discussed. Along with changing exam systems at the middle school level in Turkey, the opinion that textbooks alone are insufficient resources may prevent adequate and efficient use of textbooks. For instance, the study results obtained by Korkmaz et al. (2020) showed that the vast majority of teachers found textbooks insufficient in terms of preparation for central exams. In addition to these, it was observed that the textbooks were found to be insufficient in terms of visual elements, paper, and print quality, technical design, and organization by teachers. The fact that the textbooks used in Turkey were not found interesting by teachers and students and did not contain activities and practices that would ensure active participation of students in the course was also among the results obtained in other studies (Taşdemir, 2011; Uzunöz et al., 2010). Especially in the $7^{\text {th }}$ and $8^{\text {th }}$-grade mathematics teaching processes in both teaching environments, it was determined that the rate of textbook usage declined below 50\%. In one of the previous studies, Altun et 
al. (2004) determined that the frequency of the use of high school mathematics textbooks decreased compared to previous years and that test books were used more in preparation for the course. In this study, in which the use of middle school mathematics textbooks and the variables affecting this situation were determined, the decrease in the rate of the use of textbooks can be explained via the test technique required by the preparation process for the high school entrance exam and the insufficient representation of the new generation question types of these exams in the textbook. Similarly, a study conducted by Iş1k (2008) found that the rate and duration of teachers' textbook usage was low, there was a decrease in duration of the textbook usage compared to the previous years, and there were exercises and problems contained in textbooks. In addition, it was found that mathematics textbooks used in schools are insufficient to be prepared for central exams and there was a lack of variety of questions as well as their insufficient qualities at different levels of teaching. For example, among the similar findings of studies conducted on mathematics textbooks at different grades, it can be stated that mathematics textbooks are insufficient for teachers and students (Arslan \& Özpınar, 2009; Gökçek \& Hacısalihoğlu-Karadeniz, 2013). All these findings and previous research indicate that the textbooks are less used by the teachers in the last stages of middle school due to the fact that the questions encountered in the exams and the contents of the textbooks are not sufficiently compatible.

In terms of the professional experience, the findings showed that participants in the less experienced and experienced group reduced the use of textbooks with the shift to distance education, while participants in the very experienced group were oriented towards the use of books in this process. Moreover, the qualitative finding of the present study showed that textbook usage decreased in parallel with the increase in professional experience in face-to-face education, while teachers with more professional experience use the textbook more often in distance education. This can be explained by the fact that experienced teachers, who can use different teaching methods and content more flexibly in face-to-face classes, prefer content that they think they can perform more easily in distance education where there is a social distance. Another reason for the increase in textbook usage in distance education along with the increase in professional experience may be related to teachers' attitudes towards teaching mathematics. As a matter of fact, in studies examining the mathematical attitudes of teachers/pre-service teachers as well as in-class practice activities, it was found that mathematical attitudes affect the teaching style (Kul \& Çelik, 2017; Philipp, 2007). In this context, the frequency of the use of textbooks by mathematics teachers having different attitudes may also vary. On the other hand, Tutak and Güder (2012) found that there is no significant difference between these variables in the study in which 5thgrade teachers' opinions regarding the mathematics textbook were examined according to their professional experience and educational status. In this context, the fact that there has been a difference in textbook usage according to professional experience in this research can be explained in two ways. First, the multiple electronic resources provided by the new teaching environments may have been used more often by participants in the group who were more familiar with these technologies. Conversely, participants in a very experienced group may have advanced their courses by reflecting electronic versions of textbooks into the classroom more, as they could not offer their course notes and worksheets (limitation in writing medium, etc.) in the distance learning process.

Another variable considered in this study is the location of schools. Though distance education offers the opportunity to participate in classes regardless of time and place, these findings of the study are also important so as to see the picture of both the participation and motivation of students in rural areas and the preference of textbooks in face-to-face classes. In the predictive results of the study, it was determined that the frequency of mathematics textbook usage in face-to-face environments changed according to the type of residential area while it was determined that the distance instruction did not change according to the type of residential area, unlike the face-to-face environment. Similarly, descriptive statistics have shown that residential areas in which teacher works do not cause significant differentiation in terms of distance education regarding the textbook usage. Indeed, Bulut and Tertemiz (2013) revealed that teachers' use of mathematics textbooks differed significantly according to the socio-economic level of the schools they work in and their professional experience. Although the change in the rate of use of mathematics textbooks according to professional experience is similar to the results of this study, it seems that schools differ depending on the residential area. The reason for this finding 
can be explained by the fact that the mathematics textbook in virtual environments offers convenience to the teacher regardless of space. So, the textbooks, which are one of the unique sources for both teachers and students and which can be accessed freely, are found more useful by teachers in rural areas. On the other hand, more limited access to other auxiliary and electronic resources in rural areas (due to socio-economic reasons) may have led to extended use of textbooks. As a matter of fact, it is estimated that books will continue to be printed by the traditional method, but e-textbook technology will replace printed books in future (Soydan, 2012). In this context, in studies conducted on e-books, it was determined that the e-books were preferred by the students during the process because it provides convenience to the users in terms of time and space (Bodomo et al., 2003; Dobler, 2015; Yair, 2014). Therefore, in this research, it is not surprising that the use of textbooks in distance education does not change depending on the type of residential area. Another remarkable finding of the study is that more than half $(68 \%)$ of the participatory teachers working in rural areas are also composed of teachers in the less experienced group. Therefore, given the finding that participants in the less experienced group benefit more from mathematics textbooks in face-to-face classes, the preferences of teachers working in rural schools in these classes may be interpreted more significantly.

\section{CONCLUSION AND IMPLICATIONS}

Research results showed that the frequency of mathematics textbook usage decreased with the transition from face-to-face classes to distance education. However, it was determined that the textbooks are used more limitedly as it progressed from the $5^{\text {th }}$ grade to the $8^{\text {th }}$ grade in both teaching environments. It was concluded that the frequency of textbook usage changed according to professional experience in both face-to-face and distance learning environments, and this change was statistically significant. In parallel with the increase in professional experience in face-to-face classes, textbook usage was found to decrease. In contrast to face-to-face classes, it has been found that teachers with more professional experience in distance education classes begin to use the textbook more often. In face-to-face classrooms, it was determined that the residential area was a determining factor in terms of the frequency of the textbook usage, and the frequency of the textbook usage in distance education did not statistically significantly differ according to the residential area. In face-to-face classes, more textbooks were used in rural areas compared to urban areas. The study results showed that the difference between residential areas in terms of textbook usage decreased with the shift to distance learning environments.

For both practitioners and researchers, recommendations can be made through research results. A decrease in the rate of textbook usage in distance education classes may show that the features and content needed by instructional practitioners are insufficiently included in textbooks. In this context, it is proposed to consider the needs of teachers who are teaching in new learning environments during textbook development. In this sense, it is recommended that textbooks should be prepared in such a way that the content of the exam that students take is compatible. This study describes a general picture of the current situation through the survey design, but the needs of teachers and students are not within the scope of this study. In future research, the characteristics of textbooks that may be useful in distance education can be studied. On the other hand, other cognitive or affective variables affecting the use of mathematics textbooks (technological pedagogical content knowledge, attitude in mathematics, professional development courses, etc.) can also be evaluated in terms of face-to-face classes and distance learning. In the present study, the frequency of use of the books was evaluated in terms of some teachers and environment features. Future research can also address the purpose of using textbooks in different environments. 


\section{REFERENCES}

Altun, M., Arslan, Ç., \& Yazgan, Y. (2004). Lise matematik ders kitaplarının kullanım şekli ve sıklığı üzerine bir çalışma [A study on the use and frequency of high school mathematics textbooks]. Journal of Uludag University Education Faculty, 17, 131-147.

Arslan, S., \& Özpınar, İ. (2009). Evaluation of 6th grade mathematics textbooks along with the teacher opinions. Dicle University Journal of Ziya Gökalp Faculty of Education, 12, 97-113.

Bodomo, A., Lam, M., \& Lee, C. (2003). Some students still read books in the 21st century: A study of user preferences for print and electronic libraries. The Reading Matrix, 3(3), 34-49.

Bulut, A., \& Tertemiz, N. (2013). Examining the opinions of teachers regarding the use of primary school mathematics textbooks in terms of some variables. International Journal of Curriculum and Instructional Studies 3(5), 69-86.

Çetin, H., Aydın, S., \& Yazar, M.İ. (2019). Investigation of attitudes and needs of manipulative use of middle school mathematics teachers. International Journal of Society Researches, 10(17), 1179-1200. https://doi.org/10.26466/opus.525024

Check, J., \& Schutt, R. K. (2012). Research methods in education. Sage.

Coman, C., Țîru, L. G., Meseșan-Schmitz, L., Stanciu, C., \& Bularca, M. C. (2020). Online teaching and learning in higher education during the coronavirus pandemic: Students' perspective. Sustainability, 12(24), 10367. https://doi.org/10.3390/su122410367

Davis, E. A., \& Krajcik, J. S. (2005). Designing educative curriculum materials to promote teacher learning. Educational Researcher, 34(3), 3-14. https://doi.org/10.3102/0013189x034003003

Dobler, E. (2015). E-textbooks: A personalized learning experience or a digital distraction? Journal of Adolescent and Adult Literacy, 58(6), 482-491.https://doi.org/10.1002/jaal.391

Erbaş, A., Alacacı, C., \& Bulut, M. (2012). A comparison of mathematics textbooks from Turkey, Singapore, and the United States of America. Educational Sciences: Theory and Practice, 12(3), 2324-2330.

Fan, L., Cheng, J., Xie, S. (2021). Are textbooks facilitators or barriers for teachers' teaching and instructional change? An investigation of secondary mathematics teachers in Shanghai, China. ZDM Mathematics Education. https://doi.org/10.1007/s11858-021-01306-6

Fan, L. (2013). Textbook research as scientific research: Towards a common ground on issues and methods of research on mathematics textbooks. ZDM Mathematics Education, 45(5), 765-777. https://doi.org/10.1007/s11858-013-0530-6

Fan, L., Zhu, Y., \& Miao, Z. (2013). Textbook research in mathematics education: development status and directions. ZDM Mathematics Education, 45(5), 633-646. https://doi.org/10.1007/s11858-013-0539-X

Glasnović Gracin, D., \& Jukić Matić, J. (2016). The role of mathematics textbooks in lower secondary education in Croatia: An empirical study. The Mathematics Educator, 16(2), 31-58.

Gökçek, T., \& Çelik, S. (2020). A meta-synthesis study of research about mathematic textbooks. Pegem Journal of Education and Instruction, 10(4), 1247-1288. https://doi.org/10.14527/pegegog.2020.038

Gökçek, T., \& Hacısalihoğlu-Karadeniz, M. (2013). Reasons for choosing alternative sources instead of textbook at secondary education. Turkish Journal of Computer and Mathematics Education, 4(1), 20-31. https://doi.org/10.17762/turcomat.v4i1.48

Gueudet, G., Pepin, B., \& Trouche, L. (2013). Textbooks design and digital resources. In C. Margolinas (Ed.), Task Design in Mathematics Education: Proceedings of ICMI Study 22, July 2014. (pp. 325-337). University of Oxford.

Haggarty, L., \& Pepin, S. (2002). An investigation of mathematics textbooks and their use in English, French and German classrooms: who gets an opportunity to learn what? British Educational Research Journal, 28(4), 567-590. https://doi.org/10.1080/0141192022000005832

Howson, G. (2013). The development of mathematics textbooks: Historical reflections from a personal perspective. ZDM Mathematics Education, 45(5), 647-658. https://doi.org/10.1007/s11858-013-0511-9

Huang, C., Wang, Y., Li, X., Ren, L., Zhao, J., Hu, Y., Zhang, L., Fan, G., Xu, J., Gu, X., Cheng, Z., Yu, T., Xia, J., Wei, Y., Wu, W., Xie, X., Yin, W., Li, H., Liu, M., Xiao, Y., .. Cao, B. (2020). Clinical features of patients infected with 2019 novel coronavirus in Wuhan, China. Lancet (London, England), 395(10223), 497-506. https://doi.org/10.1016/S0140-6736(20)30183-5

Işık, A. D. (2013). Usability of e-books in education. Bartin University Journal of Faculty of Education 2(2), 395411. https://doi.org/10.14686/201322034

Işık, C. (2008). The factors affecting the use of mathematics textbook of mathematics teachers at primary education (Grades 6-8) and their expectations. Kastamonu Journal of Faculty of Education, 16(1), 163-176. 
Jhangiani, R. S., Dastur, F. N., Le Grand, R., \& Penner, K. (2018). As good or better than commercial textbooks: Students' perceptions and outcomes from using open digital and open print textbooks. Canadian Journal for the Scholarship of Teaching and Learning, 9(1), 1-22. https://doi.org/10.5206/cjsotl-rcacea.2018.1.5

Jou, M., Tennyson R. D., Wang, J., \& Huang, S.Y. (2016). A study on the usability of E-books and APP in engineering courses: A case study on mechanical drawing. Computers \& Education. 92-93, 181-193. https://doi.org/10.1016/j.compedu.2015.10.004

Korkmaz, E., Tutak, T., \& İlhan, A. (2020). Evaluation of secondary school mathematics textbooks by mathematics teachers. European Journal of Science and Technology (18), 118-128. https://doi.org/10.31590/ejosat.667689

Kul, U., \& Çelik, S. (2017). Exploration of pre-service teachers' beliefs in relation to mathematics teaching activities in classroom-based setting. International Journal of Research in Education and Science, 3(1), 245-257.

Kul, Ü., Sevimli, E., \& Aksu, Z. (2018). A comparison of mathematics questions in Turkish and Canadian school textbooks in terms of synthesized taxonomy. Turkish Journal of Education, 7(3), 136-155. https://doi.org/10.19128/turje.395162

Lau, K. H., Lam, T., Kam, B. H., Nkhoma, M., Richardson, J., \& Thomas, S. (2018). The role of textbook learning resources in e-learning: A taxonomic study. Computers \& Education, 118, 10-24. https://doi.org/10.1016/j.compedu.2017.11.005

Margolinas, C. (Ed.). (2013). Task design in mathematics education. Proceedings of ICMI Study 22. University of Oxford.

Matzavela, V., \& Alepis, E. (2021). M-learning in the COVID-19 era: physical vs digital class. Education and Information Technologies, 26, 7183-7203. https://doi.org/10.1007/s10639-021-10572-6

Mullis, I. V. S., Martin, M. O., Foy, P., Kelly, D. L., \& Fishbein, B. (2020). TIMSS 2019 international results in mathematics and science. TIMSS \& PIRLS International Study: Center website https://timssandpirls.bc.edu/timss2019/international-results/

National Council of Teachers of Mathematics (NCTM). (2014). Principles to actions: Ensuring mathematical success for all. NCTM.

Oates, T. (2014). Why textbooks count: A policy paper. Cambridge Assessment. https://www.cambridgeassessment.org.uk/Images/181744-why-textbooks-count-tim-oates.pdf

Özgeldi, M . (2012). Explaining dimensions of middle school mathematics teachers' use of textbooks. Mersin University Journal of the Faculty of Education 8(3), 24-36.

Özmantar, M., Dapgın, M., Çırak-Kurt, S., \& İlgün, Ş. (2017). Mathematics teachers' use of source books other than textbooks: reasons, results and implications. Gaziantep University Journal of Social Sciences, 16(3), 741-758. https://doi.org/10.21547/jss.322750

Pepin, B. (2019). Mathematics (E-) textbooks: help or hindrance for innovations. In S. Rezat, L. Fan, M. Hattermann, J. Schumacher, \& H. Wuschke (Eds.), Proceedings of the Third International Conference on Mathematics Textbook Research and Development: 16-19 September, Paderborn, Germany (pp. 25-27). Universitätsbibliothek Paderborn. https://doi.org/10.17619/UNIPB/1-768

Pepin, B., \& Haggarty, L. (2001). Mathematics textbooks and their use in English, French and German classrooms: A way to understand teaching and learning cultures. ZDM Mathematics Education, 33(5), 158-175. https://doi.org/10.1007/BF02656616

Pepin, B., Choppin, J., Ruthven, K., \& Sinclair, N. (2017). Digital curriculum resources in mathematics education: Foundations for change. ZDM Mathematics Education, 49(5), 645-661. https://doi.org/10.1007/s11858017-0879-Z

Pepin, B., Gueudet, G., \& Trouche, L. (2013). Re-sourcing teacher work and interaction: A collective perspective on resource, their use and transformation. ZDM Mathematics Education, 45(7), 929-943. https://doi.org/10.1007/s11858-013-0534-2

Philipp, R. A. (2007). Mathematics teachers' beliefs and affect. In F. K. Lester (Ed.), Second handbook of research on mathematics teaching and learning (pp. 257-315). Information Age.

Plianram, S., \& Inprasitha, M. (2012). Exploring elementary Thai teachers' use of mathematics textbook. Creative Education, 3(6), 692-695. https://doi.org/10.4236/ce.2012.36103

Remillard, J. T. (2005). Examining key concepts in research on teachers' use of mathematics curricula. Review of Educational Research, 75(2), 211-246. https://doi.org/10.3102\%2F00346543075002211

Rezat, S. (2011). Interactions of teachers' and students' use of mathematics textbooks. In G. Gueudet, B. Pepin, $\&$ L. Trouche (Eds.), Mathematics curriculum material and teacher development: From text to 'lived' resources (pp. 231-246). Springer.

Robinson, S., \& Stubberud, H. A. (2012). Student preferences for educational materials: Old Meets New. Academcy of Educational Leadership Journal, 16(1), 99-109.

Robitaille, D., \& Travers, K. (1992). International studies of achievement in mathematics. In D. Grouws (Ed.) Handbook of research on mathematics education (pp.687-709). Macmillan Publishing Company. 
Samat, A. A., \& Rosli, R. (2020). Exploring teachers' perceptions of primary school mathematics textbook. International Journal of Academic Research in Progressive Education and Development, 9(1), 286-300. http://dx.doi.org /10.6007/IJARPED/v9-i1/7043

Sevimli, E., \& Kul, Ü. (2015). Evaluation of the contents of mathematics textbooks in terms of compliance to technology: case of secondary school. Necatibey Faculty of Education Electronic Journal of Science and Mathematics Education, 9(1), 308-331.

Siedel, H., \& Stylianides, A. J. (2018). Teachers' selection of resources in an era of plenty: An interview study with secondary mathematics teachers in england. In L. Fan, L. Trouche, C. Qi, S. Rezat, \& J. Visnovska (Eds.), Research on mathematics textbooks and teachers' resources (pp. 119-144). Springer.

Soydan, E. (2012). E-book technology and the future of the printed book. Batman University Journal of Life Sciences, 1(1), 389-399.

Stein, M., Remillard, J., \& Smith, M. (2007). How curriculum influences students' learning. In F. Lester (Ed.), Second handbook of research on mathematics teaching and learning (pp. 557-628). Information Age.

Stephenson, J. (2018). Teaching \& learning online: new pedagogies for new technologies. Routledge.

Taşdemir, C. (2011). Evaluating of mathematic lesson books taught in first grade of elementary school according to the views of teachers (An example for Bitlis city). Dicle University Journal of Ziya Gökalp Faculty of Education, 16, 16-27.

Thompson, D. R., Senk, S. L., \& Johnson, G. J. (2012). Opportunities to learn reasoning and proof in high school mathematics textbooks. Journal for Research in Mathematics Education, 43, 253-295. https://doi.org/10.5951/jresematheduc.43.3.0253

Thomson, S., \& Fleming, N. (2004). Summing it up: Mathematics achievement in Australian schools in TIMSS 2002. ACER.

Tutak, T., \& Güder Y. (2012). The opinions of the primary $5^{\text {th }}$ grade school teachers' views about mathematics textbook. Dicle University Journal of Ziya Gökalp Faculty of Education, 19, 16-28.

Uğurel, I., Bukova-Güzel, E., \& Kula, S. (2010). Mathematics teachers' opinions and experiences related to learning tasks. The Journal of Buca Faculty of Education, (28), 103-123.

Ulusoy, F., \& İncikab1, L. (2020). Middle school teachers' use of compulsory textbooks in instructions of mathematics. International Journal for Mathematics Teaching and Learning, 21(1), 1-18.

Uzunöz, A., Engin, İ., \& Tenteriz, C. (2010). Primary school teachers' ideas concerning the new textbooks. Kastamonu Education Journal, 18(3), 871-892.

Valverde, G. A., Bianchi, L. J., Wolfe, R. G., Schmidt, W. H., \& Houang, R. T. (2002). According to the book. Using TIMSS to investigate the translation of policy into practice through the world of textbooks. Kluwer Academic Publishers.

Yair, Y. Y. (2014). Print vs. digital books in distance education. ACM Inroads, 5(1), 28-29. https://doi/10.1145/2568195.2568204

Yang, D. C., \& Sianturi, I. A. (2017). An Analysis of Singaporean versus Indonesian textbooks based on trigonometry content. EURASIA Journal of Mathematics Science and Technology Education, 13(7), 38293848. https://doi.org/10.12973/eurasia.2017.00760a

Yaşlica, E. (2020). Sanal sınıf ortamında etkileşimli öğretim materyalinin başarıya ve tutuma etkisi [The impact of interactive teaching material on success and attitude in virtual classroom environment]. Anadolu University Journal of Social Sciences, 20(1), 39-56. https://doi.org/10.18037/ausbd.700328 


\section{TÜRKÇE GENIŞLETILMIŞ ÖZET}

Eğitim ve öğretim faaliyetlerini destekleyici bir unsuru olan ders kitapları, öğretmenler ve öğrenciler tarafından eski çağlardan günümüze kadar, geçerli ve düzenli bilgilere kolayca erișebilmek üzere kullanılmaktadır. Bu sayede bilimsel bilginin kaynağına basılı veya elektronik materyaller yardımıyla kolayca ulaşım sağlanabilmektedir (Pepin, 2019). Teknolojideki gelişimin öğrenme-öğretme sürecindeki etkisinin daha fazla yaygınlaşmasıyla da birlikte, öğrenme ortamları ve öğretim içerikleri zaman ve mekandan bağımsız olacak (mobil öğrenme) biçimde tasarlanmaya başlanmıştır. Buna ilaveten, küresel ölçekte etki gösteren ve Dünya Sağlı Örgütünün pandemi olarak tanımladığı Covid19 krizi sonrasında öğretim ortamlarının büyük ölçüde uzaktan veya hibrid modellere geçişi hız kazanmış ve öğretmenler sanal sınıf ortamlarında öğretim faaliyetlerini yürütmeye başlamıştır.

İlgili alanyazında sınırlı sayıdaki çalışmada, yüz yüze sınıflarda öğretmenlerin ders kitabı kullanım tercihleri demografik değişkenler açısından ele alınmıştır (Işık, 2008; Korkmaz vd., 2020; Özgeldi, 2012; Ulusoy \& İncikab1, 2020). Bununla birlikte, yüz yüze ve uzaktan eğitim sürecinde ders kitabı kullanım sıklığını öğretmenler açısından karşılaştırılmalı olarak sorgulayan kapsamlı bir çalışmaya rastlanmamıştır. Oysa, teknolojideki gelişim ile birlikte eğitim-öğretim sürecini etkileyen diğer sosyal ve sağlık alanındaki değişimler, öğrenme yöntem ve alışkanlıklarını da değiştirilmektedir. Farklı sınıf ortamlarında ve eğitim yaklaşımlarında da kullanışlı olacak bir ders kitabının niteliklerini anlamak, hangi değişkenlerin ders kitabı kullanım sıklığını etkileyebileceğini bilmek ders kitaplarının öğrenmeöğretme sürecinde etkin kullanımına katkı sağlayacaktır. Özellikle pandemi sonrasındaki sanal sınıflarda matematik ders kitabının sahip olması gereken nitelik ve özelliklere ilişkin öğretmen düşünceleri önem kazanmaktadır. Dolayısıyla bu çalışmanın amacı, ortaokul matematik öğretmenlerinin yüz yüze ve uzaktan eğitim sürecinde ders kitabı kullanım sıklığını sınıf düzeyi, mesleki deneyim ve yerleşim bölgesi açısından karşılaştırmaktır.

Ortaokul matematik öğretmenlerinin mevcut matematik ders kitaplarını kullanma oranlarını bir kısım değişkenler açısından değerlendiren araştırma, tarama deseni üzerinden yürütülmüştür. Matematik öğretmenlerinin yüz yüze ve sanal ortamda ders kitabı kullanımı hakkındaki görüşlerini geniş çerçevede belirlemek için çevrimiçi formlar kullanılmıştır. Bu bağlamda e-anket yolu ile ulaşılabilen ve araştırmaya gönüllü olarak katılan 287 matematik öğretmeni araştırmanın katılımcılarını oluşturmaktadır. Mesleki deneyim grupları oluşturulurken TIMMS 2015 ulusal matematik ve fen ön raporundaki sınıflandırmalar ve katılımcıların dağılım frekansları dikkate alınmış ve böylece normal dağılımı sağlayacak şekilde 5 yıl ve daha az, 6 ile 15 yıl arası ve 16 yıl ve üzeri şeklinde üç gruplu bir sınıflandırmaya gidilmiştir. Bu gruplar sırasıyla az deneyimli, deneyimli ve çok deneyimli olacak şekilde isimlendirilmiş ve böylece okuyucu için açıklayıcı terminolojiler ile içeriğin yansıtılmasına dikkat edilmiştir.

Araştırma verileri, ortaokul matematik öğretmenlerinin matematik ders kitabı kullanım sıklı̆̆ını belirlemek üzere geliştirilen ve hem yüz yüze hem de çevrimiçi sınıflarda kullanılabilen Matematik Ders Kitabı İnceleme (MDKİ) formu yoluyla toplanmıştır. MDKİ formu ilköğretim matematik öğretmenliği lisans programlarında yer alan Matematik Ders Kitabı İnceleme dersine kayıtlı öğrencilerin saha gözlemleri, araştırmacıların alanyazındaki tarama verileri ve uzman görüşleri çerçevesinde hazırlanmıştır. Form demografik değişkenler ve kullanım sıklığı maddeleri olmak üzere iki bölümden oluşmaktadır. Katılımcıların yüz yüze ve sanal ortamda ders kitabı kullanımı hakkındaki görüşlerini tespit etmek üzere kullanılan MDKİ formu çevrimiçi anket uygulamaları yoluyla ve her bir öğretim ortamı için farklı zamanlarda uygulanmıştır. Sanal/yüz yüze ortamda matematik ders kitabına ilişkin öğretmenlerin görüşünü belirleyen formlar, sistemli bir şekilde katılımcılara ulaştırılmaya çalışılmıştır. Böylelikle Türkiye'nin her bölgesinde matematik öğretmenlerinden görüş alınarak araştırma, geniş kapsamda yürütülmüştür.

Araştırma verilerinin analizinde hem betimsel ve kestirimsel istatistik teknikleri kullanılmıştır. 
Öncelikle, örneklemde yer alan her bir öğretmenin ders kitabı kullanım sıklığına göre kodlanan verileri, yüzde olarak değerlendirilmiştir. Verilerin kodlanması ve kodların istatistiksel olarak değerlendirilmesi sürecinde matematik eğitimi alanında uzmanı iki akademisyen görev almıştır. Bu anlamda, farklı öğrenme ortamlarında ders kitabı kullanım sıklığı ile ders kitaplarının sınıf düzeyine göre kullanım sıkl1kları frekans cinsinden belirlenmiş ve yüzde olarak sunulmuştur. Kestirimsel istatistik sürecinde, matematik ders kitaplarının kullanım sıklığı düzeyleri ile mesleki deneyimleri ve yerleşim yeri gibi kategorik değişkenler arasındaki ilişki Ki-kare testleri kullanılarak analiz edilmiştir.

Araştırmanın bulgularına göre, yüz yüze eğitimden uzaktan eğitime geçiş ile birlikte matematik ders kitabının kullanım sıklığının azaldığı belirlenmiştir. Matematik ders kitaplarının farklı öğrenme ortamlarındaki kullanım oranları kategorik olarak incelendiğinde "Nadiren (0-25\%)" ile "Önemli oranda (51-75\%)" kategorilerindeki farklılığın diğer kategorilere göre daha belirgin olduğu gözlenmiştir. Bu anlamda, ders kitabına matematik öğretim sürecinde daha az başvuran katılımcıların yer aldığı" Nadiren" kategorisinde, yüz yüze sınıflardaki katılımcıların \%24'ü bulunurken, aynı kategoride bulunan uzaktan eğitim sınıflarındaki katılımcı oranı \% 41 'dir. Ders içeriklerinin yarısından fazlasını ders kitabı kaynağına başvurarak oluşturan katılımcıların yer aldığı kategori "Önemli oranda" iken bu kategorideki katılımcıların uzaktan eğitime (\%11) kıyasla yüz yüze eğitimde (\%30) daha fazla olduğu görülmektedir. Ayrıca sınıf düzeyi ve ders kitabı kullanım sıklığ1 verilerinin çapraz karşılaştırması ile katılımcıların farklı öğretim ortamlarındaki içerik tercihleri değerlendirilmiştir. Hem yüz yüze hem de uzaktan eğitim sürecinde ders kitabı kullanım oranının en yüksek olduğu sınıf düzeyi 5. sınıf iken, en düşük olduğu sınıf düzeyi ise 8 . sinıftır. Öte yandan hem yüz yüze hem de uzaktan eğitim sürecinde sınıf düzeyi arttıkça ders kitabı kullanım sıklığının azaldığı görülmektedir. Her iki öğretim ortamında da ders kitabı kullanımının dikkate değer oranda düşmeye başladığı sınıf düzeyi 7. sınıf olarak tespit edilmiştir. Bununla birlikte, tüm sınıf kademeleri için yüz yüze sınıflardaki ders kitabı kullanım oranının uzaktan eğitim sınıflarından daha yüksek olduğu görülmüştür. Ayrıca yüz yüze sınıf ortamında, matematik öğretmenlerinin ders kitabı kullanma sıklığı ile deneyimleri arasındaki farklılığın istatistiksel olarak anlamlı olduğu tespit edilmiştir $\left(\mathrm{p}<0.05 ; \mathrm{X}^{2}=42.940\right)$. Uzaktan eğitim sinıflarında da matematik öğretmenlerinin ders kitabı kullanma sıklığı ile deneyimleri arasındaki farklılık anlamlı çıkmıştır $\left(\mathrm{p}<0.05 ; \mathrm{X}^{2}=23.036\right)$. Dolayısıyla her iki öğretim ortamındaki matematik ders kitabı kullanım sıklığının mesleki deneyime göre değiştiği söylenebilir. Diğer yandan katılımcı öğretmenlerin mesleki deneyimlerine göre farklı öğretim ortamlarındaki ders kitabı kullanım oranları incelenmiştir. Az deneyimli grupta yer alan katılımcıların ders kitabı kullanım sıklığının yüz yüze eğitimden uzaktan eğitime geçişle birlikte azaldığı gözlenmiştir. Beş yıl ve altında mesleki deneyime sahip olan katılımcıların yüz yüze eğitim sürecinde \%30'undan fazlası, uzaktan eğitim sürecinde ise $\% 20$ 'sinden daha azı, önemli oranda ve büyük oranda kategorileri içerisinde değerlendirilmiştir.

Yüz yüze sınıf ortamında, matematik öğretmenlerinin ders kitabı kullanma sıklığı ile yerleşim yeri arasındaki ilişkiye bakıldığında ise anlamlı bir farklılık bulunmuştur $\left(\mathrm{p}<0.05 ; \mathrm{X}^{2}=7.968\right)$. Yüz yüze eğitim sürecinden farklı olarak uzaktan eğitim sürecinde yerleşim türüne göre anlamlı bir farkl11ık bulunmamıştır. Başka bir ifadeyle matematik öğretmenlerinin uzaktan eğitim sınıflarındaki ders kitabı kullanma sıklığı ile yerleşim yeri arasında anlamlı bir ilişki olmadığı görülmektedir $\left(\mathrm{p}>0.05 ; \mathrm{X}^{2}\right.$ $=10.753$ ). Kentsel yerleşim bölgelerinde görev yapan katılımc1 öğretmenlerin uzaktan eğitim sürecine kıyasla yüz yüze eğitimde ders kitabını daha sık kullandıkları tespit edilmiştir. Kırsal yerleşim bölgelerinde görev yapan katılımcıların yüz yüze sınıflarda "Önemli oranda" ve "Büyük oranda", uzaktan eğitim sınıflarında ise "Nadiren" ve "Sınırlı" kategorisi içerisinde daha sık yer aldıkları belirlenmiştir. Bu bulgu, kırsal bölgelerde katılımcıların ders kitabı kullanımının yüz yüze eğitimden uzaktan eğitime geçiş ile birlikte azaldığını ortaya koymaktadır. Ders kitabı kullanımının öğretim ortamındaki değişime göre nasıl farklılaştığı, yerleşim bölgesi dikkate alınarak analiz edildiğinde, yüz yüze eğitimden uzaktan eğitime geçiş ile birlikte hem kentsel hem de kırsal bölgelerde ders kitabı kullanım sıklığının azaldığı, ancak kırsal bölgelerdeki azalış oranının daha belirgin olduğu söylenebilir. 